\title{
Pregnancy outcome in working women with work place stress
}

\author{
Kusuma Naik M. V.*, Vedavathy Nayak, Renuka Ramaiah, Praneetha
}

Department of Obstetrics and Gynecology, ESIC MC and PGIMSR, Rajajinagar, Bangalore, Karnataka, India

Received: 08 June 2017

Accepted: 12 June 2017

\section{*Correspondence:}

Dr. Kusuma Naik M. V.,

E-mail: kusumamv.naik@gmail.com

Copyright: (c) the author(s), publisher and licensee Medip Academy. This is an open-access article distributed under the terms of the Creative Commons Attribution Non-Commercial License, which permits unrestricted non-commercial use, distribution, and reproduction in any medium, provided the original work is properly cited.

\begin{abstract}
Background: The employment rate of mothers has increased worldwide in recent years. So, there is concern about possible effects of work related risk factors and pregnancy outcome in working women. As a growing percentage of women work outside home before, during, and after pregnancy in most countries and its related occupational factors deserve to be studied in relation to pregnancy outcomes. To identify the effect of work place stress, on pregnancy and perinatal outcome.

Methods: 100 pregnant working women, who were visiting the antenatal care unit and labour room taken into study. They were interviewed using predesigned questionnaire, Physical activity questionnaire, Workplace Stress Survey. Statistical analysis performed using SPSS version 21.

Results: Mean age was $27 \mathrm{yrs}$, with hrs of working/wk of $47 \mathrm{hrs}, 41$ women studied were working in garment factories, $46 \%$ of them had complications during their antenatal period, $56 \%$ of them were primigravidas. Among studied working conditions, working more than 40 hours/ week was significantly associated with high rates of preterm delivery (12\%) and Small for gestational age (SGA) (22\%) was significantly increased with high work stress. Conclusions: Among the studied, work conditions for working women working more than 40 hours/week, social stress index were found to be a significant risk factor for adverse pregnancy outcomes. General practice physical activity (GPPA) $80 \%$ of both active and moderately active women had some problems. In work place stress survey (WSS), 100\% of women encountering problems at work place had problems during their pregnancy, $72 \%$ of women who handled stress moderately had problems. Therefore, as long as the health of the pregnant woman permits her to continue work during pregnancy that is not stressful or overloading for her, no adverse effect on pregnancy outcomes is expected.
\end{abstract}

Keywords: GPPA, Pregnancy outcome, SGA, WSS

\section{INTRODUCTION}

The potential impact of employment on pregnancy is an important issue due to the increasing number of woman entering the labor force and continuing employment throughout pregnancy. ${ }^{1}$ The majority of women remain well through their pregnancy. So, pregnancy should not be regarded as either an illness, or a contraindication for work. However, a working pregnant woman may be exposed to particular hazards that might potentially cause adverse pregnancy outcomes for her or her fetus. ${ }^{2}$ Heavy lifting, standing for long hours, irregular working hours, shift work have all been reported to be associated with adverse pregnancy outcomes such as spontaneous abortion, still births, preterm delivery, low birth weight and congenital malformations. ${ }^{3}$

Physical exertion has been suggested as a risk factor for adverse pregnancy outcome due to the combined effects of vasoconstriction, myometrial contraction, reduced 
plasma volume, and diversion of blood flow away from the placental bed, diminution of uteroplacental blood flow with resultant fetal hypoxia. This, along with possible hormonal imbalance, may have deleterious effects on the fetus. ${ }^{4}$ Despite the probability that working women may have less favorable pregnancy outcomes, some studies of the health among working women provide conflicting results and leave the issue unresolved. Moreover, only a few such studies have been conducted in the developing countries, which necessities further study to clarify these issues. ${ }^{1}$

Aim and objectives of present work were to study the relation between work related risk factors and some adverse pregnancy outcome among a representative sample of working pregnant women attending the antenatal care at ESIC MC and PGIMSR, Bangalore.

\section{METHODS}

A prospective study involved 100 pregnant women who were visiting the antenatalcare clinic and labour room at ESIC MC and PGIMSR, Rajajinagar, Bangalore. The target group were enrolled in the study during their antenatal care visit or after admission to labour room, after taking their written consent to participate in the study, the purpose of study was explained and included in the study.

\section{Exclusion criteria}

Women who had medical disorders pregestational.

All participants were interviewed by trained personnel using a predesigned questionnaire that included the following data:

\section{Personal information}

Age, education status, hours of travelling to the work,

\section{Obstetric history}

Duration of pregnancy at first antenatal care visit, expected date of delivery, history of present and past conceptions if any. Number of children, history of abortion, still birth or low birth weight

\section{Occupational history}

Type of work, work pattern (daytime work or shift work), time taken to reach work place, working hours/week, prolonged physical strain or fatigue, exposure to potential occupational hazards as radiation, chemical exposure, biological agents. Work categories Type and nature of work were then categorized into 5 main groups (Clerical workers, tailors Elementary occupations, Health Professionals, Teaching Professionals, Technicians according to the International Standard Classification of Occupations (ISCO), 2008). ${ }^{5}$

\section{Adverse pregnant outcomes}

The main outcomes assessed during follow up included

- Perinatal death (abortion, still birth or early neonatal deaths)

- Preterm delivery (delivery of the fetus before 37 completed week of gestation)

- Small for gestational age (SGA) (birth weight below the 10th percentile)

- $\quad$ Rate of operative delivery

Physical activity questionnaire

General Practice Physical Activity Questionnaire (GPPAQ) It generates a simple 4-level Physical Activity Index (PAI) - categorizing (Table 1). ${ }^{6}$

- Active

- Moderately Active

- Moderately Inactive, and

- Inactive.

Table 1: The 4-level physical activity index (PAI).

\begin{tabular}{|c|c|}
\hline Grade & Physical activity \\
\hline Inactive & $\begin{array}{l}\text { Sedentary job and no physical exercise } \\
\text { or cycling }\end{array}$ \\
\hline $\begin{array}{l}\text { Moderately } \\
\text { inactive }\end{array}$ & $\begin{array}{l}\text { Sedentary job and some but }<1 \text { hour } \\
\text { physical exercise and / or cycling per } \\
\text { week or } \\
\text { Standing job and no physical exercise or } \\
\text { cycling }\end{array}$ \\
\hline $\begin{array}{l}\text { Moderately } \\
\text { active }\end{array}$ & $\begin{array}{l}\text { Sedentary job and } 1-2.9 \text { hours physical } \\
\text { exercise and / or cycling per week or } \\
\text { Standing job and some but }<1 \text { hour } \\
\text { physical exercise and / or cycling per } \\
\text { week or Physical job and no physical } \\
\text { exercise or cycling. }\end{array}$ \\
\hline Active & $\begin{array}{l}\text { Sedentary job and } \geq 3 \text { hours physical } \\
\text { exercise and / or cycling per week or } \\
\text { Standing job and } 1-2.9 \text { hours physical } \\
\text { exercise and / or cycling per week or } \\
\text { Physical job and some but }<1 \text { hour } \\
\text { physical exercise and / or cycling per } \\
\text { week or Heavy manual job. }\end{array}$ \\
\hline
\end{tabular}

\section{Workplace stress survey}

The American institute of stress has created a job stress survey that can help reveal employee stress levels. Survey participants are asked to assign a number from 1 to 10 statements that describe amount of work stress and work satisfaction. ${ }^{7}$ According to this questionnaire, three levels of work stress were identified

- $\quad$ Mild stress (A score of 10-30)

- Moderate stress (A score of 40-60)

- $\quad$ Severe stress (A score of 70- 100) 
Table 2: Workplace stress survey.

\begin{tabular}{|c|c|c|c|c|}
\hline S.No & Questions & $\begin{array}{l}\text { Strongly disagree } \\
\left(\begin{array}{llll}1 & 2 & 3 & 4\end{array}\right)\end{array}$ & $\begin{array}{l}\text { Agree Somewhat } \\
\left(\begin{array}{l}567)\end{array}\right.\end{array}$ & $\begin{array}{l}\text { Strongly agree } \\
\left(\begin{array}{lll}8 & 9 & 10\end{array}\right)\end{array}$ \\
\hline 1 & $\begin{array}{l}\text { I can't honestly say what I really think or } \\
\text { get things off my chest at work. }\end{array}$ & 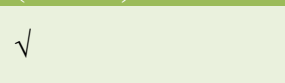 & & \\
\hline 2 & $\begin{array}{l}\text { My job has a lot of responsibility, but I } \\
\text { don't have very much authority. }\end{array}$ & $\sqrt{ }$ & & \\
\hline 3 & $\begin{array}{l}\text { I could usually do a much better job if I } \\
\text { were given more time. }\end{array}$ & $\sqrt{ }$ & & \\
\hline 4 & $\begin{array}{l}\text { I seldom receive adequate } \\
\text { acknowledgement or appreciation when my } \\
\text { work is really good. }\end{array}$ & $\sqrt{ }$ & & \\
\hline 5 & $\begin{array}{l}\text { In general, I am not particularly proud or } \\
\text { satisfied with my job. }\end{array}$ & & $\sqrt{ }$ & \\
\hline 6 & $\begin{array}{l}\text { I have the impression that I am repeatedly } \\
\text { picked on or discriminated against at work. }\end{array}$ & & $\sqrt{ }$ & \\
\hline 7 & $\begin{array}{l}\text { My workplace environment is not very } \\
\text { pleasant or safe. }\end{array}$ & & $\sqrt{ }$ & \\
\hline 8 & $\begin{array}{l}\text { My job often interferes with my family and } \\
\text { social obligations, or personal needs. }\end{array}$ & & & $\sqrt{ }$ \\
\hline 9 & $\begin{array}{l}\text { I tend to have frequent arguments with } \\
\text { superiors, coworkers or customers. }\end{array}$ & & & $\sqrt{ }$ \\
\hline 10 & $\begin{array}{l}\text { Most of the time I feel I have very little } \\
\text { control over my life at work. }\end{array}$ & & & $\sqrt{ }$ \\
\hline
\end{tabular}

Add up the replies to each question for your Total Job Stress Score __. If you score between 10-30, you handle stress on your job well; 40-60, moderately well; 70-100 you are encountering problems that need to be resolved.

\section{Statistical analysis}

Data was tabulated and statistically analyzed using SPSS version 21, chi square test and Odds ratio were used to study the association between work related risk factors and studied pregnancy outcomes.

\section{RESULTS}

The mean age included in the study was $27 \mathrm{yrs}$, with mean of $47 \mathrm{hrs} /$ week of working hours, $5.4 \mathrm{hrs}$ of sitting/day and $2.5 \mathrm{hrs} /$ day of standing with standard deviation of $2.8 \mathrm{hrs}$ i.e 2.5 to $5 \mathrm{hrs}$ of standing /day at work place.
The mean of travel time to work place is 34 min with SD of 34-60 min. Among the studied pregnant working women $56 \%$ were primigravidas and $44 \%$ were multigravidas.

Among the 5 working categories under which the women were classified, $50 \%$ of them were tailors which involves a strenuous work pattern, $15 \%$ of them were health professionals which included staff nurses and doctors, $15 \%$ technician which involves prolonged standing at work place, $17 \%$ of them were clerical workers involving prolonged sitting.

Table 3: Mean and SD of age and work-related stress factors.

\begin{tabular}{|llllll} 
Age & Age in years & $\begin{array}{l}\text { Hours of } \\
\text { work/wk }\end{array}$ & $\begin{array}{l}\text { Hours of } \\
\text { standing/day }\end{array}$ & $\begin{array}{l}\text { Hours of } \\
\text { sitting/day }\end{array}$ & $\begin{array}{l}\text { Travel time } \\
\text { in min }\end{array}$ \\
\hline Mean & 27 & 47 & 2.5 & 5.4 & 34 \\
\hline Standard deviation & 4 & 6 & 2.8 & 2.9 & 30 \\
\hline
\end{tabular}

Table 4 shows the pregnancy outcome in these women. $46 \%$ of women had antenatal complications in the form of miscarriages, preterm, PROM, medical disorders, APH, IUGR. $41 \%$ of women had intrapartum complications in the form of operative deliveries, $\mathrm{PPH}$, postpartum anemia, with one case of postpartum eclampsia $22 \%$ of women had small for gestation babies, $35 \%$ of the new borns required NICU admissions for 
hyperbilirubinemia, sepsis, meconium aspiration syndrome, preterm care, $2 \%$ of perinatal mortality due to severe preterm complications and meconium aspiration syndrome.

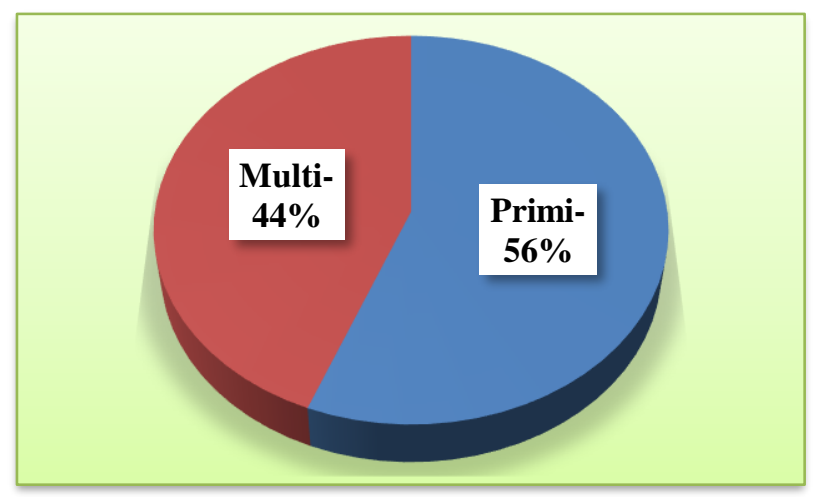

Figure 1: Parity among working women.

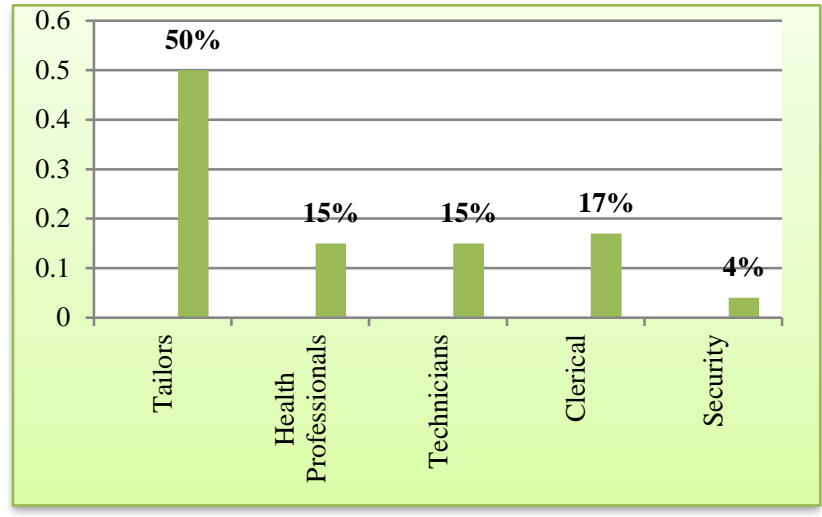

Figure 2: Work categories.

Table 5 shows the occurrence of medical disorders among working women. $15 \%$ of women had anemia, $15 \%$ of them had hypertensive disorder of pregnancy can be explained due to increased number of primigravidas in the study. With $6 \%$ of isolated oligamnios.

Table 4: Pregnancy outcome.

\begin{tabular}{|l|l|}
\hline Pregnancy outcome & $\%$ \\
\hline Antenatal complications & 46 \\
\hline Intrapartum complications & 41 \\
\hline Operative delivery & 47 \\
\hline Threatened abortion & 3 \\
\hline Abortions & 6 \\
\hline Term gestation & 82 \\
\hline Preterm gestation & 18 \\
\hline Small for gestational age (SGA) & 22 \\
\hline Perinatal mortality & 2 \\
\hline NICU admissions & 35 \\
\hline
\end{tabular}

Table 7 shows the physical activity index of the working pregnant women, $63 \%$ of them were in active category who were doing physical activity with 1-2hrs of waling or manual work, and $81 \%$ of the active women had some complications related to antenatal, intrapartum or postpartum complications. $37 \%$ of them were moderately active, $75 \%$ of them had complications.

Table 5: Prevalence of medical disorders among working women.

\begin{tabular}{|ll|}
\hline Medical disorders & \\
\hline Hypertensive disorders of pregnancy & $15 \%$ \\
\hline Gestational diabetes mellitus & $12 \%$ \\
\hline Anemia & $15 \%$ \\
\hline Isolated Oligamnios & $6 \%$ \\
\hline Hypothyroidism & $11 \%$ \\
\hline
\end{tabular}

Table 6: Postpartum complications.

\begin{tabular}{ll} 
Postpartum complications & \\
Postpartum hemorrhage & 8 \\
\hline Postpartum psychosis & 8 \\
\hline Eclampsia & 1 \\
Anemia & 4
\end{tabular}

Table 7: General practice physical activity and complications.

\begin{tabular}{|lccc|}
\hline GPPA & Active & Moderately active & \\
\hline $\begin{array}{l}\text { No } \\
\text { complications }\end{array}$ & 12 & 9 & 21 \\
\hline $\begin{array}{l}\text { Some } \\
\text { complications }\end{array}$ & 51 & 28 & 79 \\
\hline & 63 & 37 & 100 \\
\hline
\end{tabular}

Table 8 show stress level at work place among the studied women, $68 \%$ of them belonged to the category moderately well i.e, with a score in b/w 40-60 these employees are handling the stress moderately well at work place and $72 \%$ of them had some complications during their course of pregnancy. $19 \%$ of them handled stress very well. $13 \%$ of them experienced problems at their work place and all of them had some complications during their pregnancy and delivery.

Table 9: Work stress survey.

\begin{tabular}{|lllll|}
\hline WSS & EP & HSW & MW & \\
\hline $\begin{array}{l}\text { No } \\
\text { complications }\end{array}$ & 0 & 1 & 19 & 20 \\
\hline $\begin{array}{l}\text { Some } \\
\text { complications }\end{array}$ & 13 & 18 & 49 & 80 \\
\hline & 13 & 19 & 68 & 100 \\
\hline
\end{tabular}

\section{DISCUSSION}

This prospective study involved 100 pregnant women who were visiting the antenatal care clinic and labour room at ESIC MC and PGIMSR, Bangalore. As our hospital caters the working population who have been insured under government insurance, the study involved these pregnant women. 
Results showed the mean age of $27 \mathrm{yrs}, 47 \mathrm{hrs}$ of working/week, travelling time of $34 \mathrm{~min}$ to the work place and a mean of $2 \mathrm{hrs} 30 \mathrm{~min}$ of standing during the work. $56 \%$ of them were primigravidas and $50 \%$ of them belong to tailors in the work categories. Among pregnancy related complications, $45 \%$ of them had antenatal complications related to pregnancy, with $22 \%$ of small for gestation babies, $18 \%$ of them had preterm deliveries with $35 \%$ of the babies had NICU admissions.

Work stress survey showed $13 \%$ of them were encountering problems at work place and needed change of work, $68 \%$ of them managed the stress level at work moderately well. All the mothers were active or moderately active scored using GPPA level, none of them belong to inactive or moderately inactive. GPPA $80 \%$ of both active and moderately active women had some problems.

As there are very few studies in developing countries regarding the outcome of pregnancy in working women, it was difficult to compare the results. Small for gestational age is significantly high with severe work stress index and this finding supported by a possible biological mechanism linking maternal stress and birth outcomes indicates that stress triggers the production of placental corticotrophin releasing hormone (CRH), which in turn results in reduced gestational age and low birth weight. $^{13,14}$

As per the study of Hathout HM et al, the risk of preterm delivery and perinatal death was significantly higher among the age group more than 35 years of age, Perinatal death was reported in $11.5 \%$ vs. $6 \%$ for working compared to non-working subjects. Studying working characteristics in relation to pregnancy outcomes, there was significant high prevalence of preterm delivery in women working more than 40 hours/ week during pregnancy. ${ }^{15}$

Banerjee et al studied perinatal mortality in employed women, concluded that PNM is increased in women after joining the work. ${ }^{4}$ As per the study of Lee et al, small for gestational age is significantly high with severe work stress index, possible biological mechanism. ${ }^{12}$

\section{CONCLUSION}

A Significant relationship was detected between working Status and perinatal death. Socio demographic factors found to affect pregnancy outcomes, including older maternal age. Among the studied working conditions, working more than 40 hours/ week and work stress index were significantly associated with high rates of SGA. More studies needed with more sample size and multi centeric studies. The pregnancy outcome and GPPA has to be compared with the non working women, as women as such in developing countries undergo more physical and mental stress be it at home or work place.
Many studies are small in terms of the number of women exposed and the number of abnormal outcomes. A large number of non-occupational factors, many still unknown, affect the pregnancy outcome. Working $32 \mathrm{hrs}$ or more in pregnancy is as risky as smoking during pregnancy so the policy makers should be sanitized regarding this, in providing a good working condition and fixed working hours.

\section{ACKNOWLEDGMENTS}

Authors would like to thank patients, colleagues, postgraduate students for their contribution to the work.

\section{Funding: No funding sources}

Conflict of interest: None declared

Ethical approval: The study was approved by the Institutional Ethics Committee

\section{REFERENCES}

1. Arafa M, Amine T, Abdel Fattah M. Association of maternal work with adverse perinatal outcome. CaN J Public Health. 2007;98:217-21.

2. Royal College of Physicians. Physical and shift work in pregnancy. Occupational aspects of management a national guideline; 2009.

3. Mozurkewich EL, Luke B, Avni M, Wolf FM. Working conditions and adverse pregnancy outcome: A meta-analysis. Obstet Gynecol. 2000;95:623-35.

4. Banerjee B. Physical hazards in employment and pregnancy outcome. Indian $\mathrm{J}$ Comm Med. 2009;34:89-93.

5. International Labour Organization. International Standard Classification of Occupations (ISCO-08). Structure, index correspondence with ISCO-88 2008; 1 .

6. The General Practice Physical Activity Questionnaire (GPPAQ), Department of Health; 2006.

7. Workplace stress survey of The American Institute of Stress (AIS); 2011. Available at http://www.stress.org/wpcontent/uploads/2011/08/Workplace-StressSurvey.pdf)

8. Niedhammer I, O'Mahony D, Daly S, Morrison J, Kelleher C. Occupational predictors of pregnancy outcomes in Irish working women in the Lifeways cohort. BJOG. 2009;116:943-52.

9. Pompeii LA, Savitz DA, Evenson KR, Rogers B, McMahon M. Physical exertion at work and the risk of preterm delivery and small-for-gestational-age birth. Obstet Gynecol. 2005;106:1279-88.

10. Zhu JL, Hjollund NH, Olsen J. Shift work, duration of pregnancy, and birth weight: the National Birth Cohort in Denmark. Am J Obstet Gynecol. 2004;191:285-91.

11. Croteau A, Marcoux S, Brisson C. Work activity during pregnancy, preventive measures, and the risk 
of preterm delivery. Am J Epidemiol. 2007;166:95165.

12. Lee BE, Ha M, Park H, Hong YC, Kim Y, Kim YJ, et al. Psychosocial work stress during pregnancy and birth weight. Pediatr. Perinat Epidemiol. 2011;25:246-54.

13. Hobel C, Culhane, J. Role of psychosocial and nutritional stress on pregnancy outcome. J Nutr. 2003;133:1709S-17S.

14. Lockwood CJ. Stress-associated preterm delivery: The role of corticotropin releasing hormone. Am J Obstet Gynecol. 1999;180:S264-S6.
15. Hathout HM, El-Dalatony MM, Anwar MM, AlBatanony MA, Shehata NA. Work related risk factors and pregnancy outcome between working women. Pyrex J Res Environ Studies. 2015;2(3):1519.

Cite this article as: Naik KMV, Nayak V, Ramaiah $R$, Praneetha. Pregnancy outcome in working women with work place stress. Int J Reprod Contracept Obstet Gynecol 2017;6:2891-6. 